\title{
Hydrogen Output from Catalyzed Radiolysis of Water
}

\author{
Alexandru Cecal and Doina Humelnicu \\ "Al.I. Cuza" University, Department of Chemistry, Iasi, \\ Romania
}

\section{Introduction}

Energy is the source of the vitality of industrial civilization and a necessary condition to save the world from poverty.

Current methods of generating energy for the industrial civilization undermine local, regional, global environmental conditions, and are based mainly on the processing of fossil resources.

Nowadays, the dawn of a new renewable energy revolution is occurring. It is the use of hydrogen instead of using oil and its derivatives. The stakes are global. The fight against the greenhouse effect requires finding a solution for the production of green energy.

The relatively new method of producing electricity is based on conversion, in fuel cells, of heat and energy of certain chemical substances, in electricity.

Since fuel cells convert fuel directly in electricity two to three times more efficiently than the thermodynamic conversion, the fuel cell is, by definition, a very efficient technology and, being a potential source of high energy still, clean and, compatible with renewable energy policy, reliable and sustainable over time (does not contain moving parts).

Hydrogen is the key to the future of energy having the highest energy content per unit weight of all known fossil. When burned in an engine, hydrogen produces zero issues; when the power source in a fuel cell, clean waters it is the only residue at $250-300{ }^{\circ} \mathrm{C}$ (International Atomic Energy Agency, [IAEA], 1999; Ohta\&Veziroglu, 2006; Veziroglu, 2000). Combined with other technologies, such as carbon capture and storage, renewable energies, fusion energy, it is possible that the fuel cell will generate in future energies without harmful programs. Hydrogen is the only energy carrier making it possible to drive an aircraft using solar energy.

At the beginning of the XXIst century it is assumed that fuel cells will become a pervasive technology; hydrogen as fuel is becoming increasingly presented as the "solution", also by carmakers, ecologists, and governments who do not want to impose unpopular measures to limit car traffic.

The use of hydrogen will extend from cell phones to electric power plants.

Implementing the "hydrogen economy" will lead to changes not seen in the XIX century and early XX century when the world went through the experience of the last energy revolution. Environmentalists argue that there is no alternative to a hydrogen based energy system because the reserves of exploitable oil and natural gas, indispensable resource materials not 
only in energy industry, but also in petrochemicals (holds might miss today plastics), will be completely exhausted in less than a century.

T. N. Veziroglu summarizes some properties that recommend the use of hydrogen as energy carrier produced from unconventional technologies, because hydrogen is a concentrate (energy) sources of primary energy, presented to the consumer in a convenient form, having a relatively cheap production cost as a result of technological refinements. Moreover hydrogen has a high efficiency of converting in various forms of energy and represents an inexhaustible source, considering that it is obtained from water, and by use it becomes water.

Hydrogen production and consumption is a closed cycle, that maintains constant power production - water, and represent a classic cycle of raw material recycling - it is the easiest and cleanest fuel. Burning hydrogen is almost without polluting emissions, excepting $\mathrm{NO}_{\mathrm{x}}$, which can also be removed by proper adjustment of combustion conditions. It has a gravimetric "energy density" higher than any other fuel.

Hydrogen can be stored in several ways: gas at normal pressure or high pressure, as liquid or solid form of hydrides and can be transported long distances in any one of the above mentioned forms.

Assessing the effects of global economic shift to energetic system based on hydrogen it can be established that environmental pollution through energy production will not be a problem and hydrogen economy will lead to industrial transformations comparable to those produced in the microelectronics industry;

Moreover economic resources, financial, intellectual, intended for energy today and environmental and ecological problems, will be geared towards solving, for the good of mankind, other productive tasks. Life will get better. The literature state that the idea of a "hydrogen economy" would have been born and developed under the impact of oil shock, using hydrogen as fuel being presented as the last cry of modernity. In fact, however, using hydrogen as a "universal fuel" devoid of pollutant emissions appeared long before the oil shock in 1973.

The literature state that the idea of a "hydrogen economy" would have been born and developed under the impact of oil shock, using hydrogen as fuel being presented as the last cry of modernity. In fact, however, using hydrogen as a "universal fuel" devoid of pollutant emissions appeared long before the oil shock in 1973.

\section{Hydrogen production using the heat resulted in nuclear reactors after splitting the U-235 or Pu-239 nuclei}

A series of tests are known to produce hydrogen by water splitting by making calls to the thermochemical cycles (hybrid) initiated by heat inside the reactor cores from fission of U235, Pu-239, etc. (Besenbuch et al. 2000; Rahier et al., 2000; Tashimo et al., 2003, Verfondern, 2007)

An outline of such a plant for water decomposition through cycles of thermochemical reactions initiated by heat from inside a nuclear reactor is presented below:

To this end it used a series of thermochemical cycles or hybrid cycles that have been developed in different types of specialized research institutes or companies with business in areas of nuclear energy: General Atomics (USA) JAEA, Julich JRC, NRC -Ispra and other units from France, China, South Korea, Russia etc. 


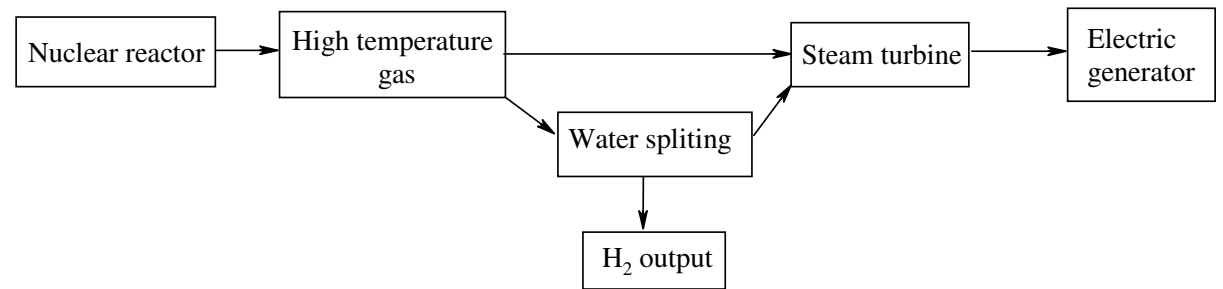

a. Sulfur-iodine cycle is shown by the sequence of reactions that occur at different temperatures:

$$
\begin{gathered}
\left(9 \mathrm{I}_{2}\right)_{1}+\left(\mathrm{SO}_{2}\right)_{\mathrm{g}}+\left(16 \mathrm{H}_{2} \mathrm{O}\right)_{1} \stackrel{120^{\circ} \mathrm{C}}{\longrightarrow}\left(2 \mathrm{HI}+10 \mathrm{H}_{2} \mathrm{O}+8 \mathrm{I}_{2}\right)_{1}+\left(\mathrm{H}_{2} \mathrm{SO}_{4}+4 \mathrm{H}_{2} \mathrm{O}\right)_{1} \\
\left(2 \mathrm{HI}+10 \mathrm{H}_{2} \mathrm{O}+8 \mathrm{I}_{2}\right)_{1} \stackrel{230^{\circ} \mathrm{C}}{\longrightarrow}(2 \mathrm{HI})_{\mathrm{g}}+\left(10 \mathrm{H}_{2} \mathrm{O}+8 \mathrm{I}_{2}\right)_{1} \\
(2 \mathrm{HI})_{\mathrm{g}} \stackrel{330^{\circ} \mathrm{C}}{\longrightarrow} \mathrm{H}_{2}+\left(\mathrm{I}_{2}\right)_{\mathrm{g}} \\
\left(\mathrm{H}_{2} \mathrm{SO}_{4}+4 \mathrm{H}_{2} \mathrm{O}\right)_{1} \stackrel{330^{\circ} \mathrm{C}}{\longrightarrow}\left(\mathrm{H}_{2} \mathrm{SO}_{4}\right)_{1}+\left(4 \mathrm{H}_{2} \mathrm{O}\right)_{1} \\
\left(\mathrm{H}_{2} \mathrm{SO}_{4}\right)_{1} \stackrel{360^{\circ} \mathrm{C}}{\longrightarrow}\left(\mathrm{H}_{2} \mathrm{SO}_{4}\right)_{\mathrm{g}} \\
\left(\mathrm{H}_{2} \mathrm{SO}_{4}\right)_{\mathrm{g}} \stackrel{400^{\circ} \mathrm{C}}{\longrightarrow}\left(\mathrm{SO}_{3}\right)_{\mathrm{g}}+\left(\mathrm{H}_{2} \mathrm{O}\right)_{\mathrm{g}} \\
\left(\mathrm{SO}_{3}\right)_{\mathrm{g}} \stackrel{870^{\circ} \mathrm{C}}{\longrightarrow}\left(\mathrm{SO}_{2}\right)_{\mathrm{g}}+1 / 2 \mathrm{O}_{2}
\end{gathered}
$$

At first, through the Bunsen reaction, there result two-phase nemiscible acids: $\mathrm{HI}$ and $\mathrm{H}_{2} \mathrm{SO}_{4}$.

These oxides, under the influence of high temperature, will decompose releasing hydrogen (and oxygen), and $\mathrm{I}_{2}$ and $\mathrm{SO}_{2}$, which will restore (as reactants) the Bunsen reaction.

b. Westinghouse cycle_takes place through two reactions, due to sulfuric acid:

$$
\begin{gathered}
\left(\mathrm{H}_{2} \mathrm{SO}_{4}\right)_{\mathrm{g}} \stackrel{850^{\circ} \mathrm{C}}{\longrightarrow}\left(\mathrm{SO}_{2}\right)_{\mathrm{g}}+\left(\mathrm{H}_{2} \mathrm{O}\right)_{1}+1 / 2 \mathrm{O}_{2} \\
\left(\mathrm{SO}_{2}\right)_{\mathrm{g}}+\left(2 \mathrm{H}_{2} \mathrm{O}\right)_{1} \stackrel{100^{\circ} \mathrm{C}}{\longrightarrow}\left(\mathrm{H}_{2} \mathrm{SO}_{4}\right)_{1}+\mathrm{H}_{2}
\end{gathered}
$$

The second reaction takes place in an electrolytic cell at low temperature when there result hydrogen and sulfuric acid in the aqueous phase at a potential of $0.17 \mathrm{~V}$ and at a pressure of about $1 \mathrm{MPa}$. Then the cycle is repeated with gaseous $\mathrm{H}_{2} \mathrm{SO}_{4}$.

c. UT-3 cycle, developed in Japan, is represented by the following reactions:

$$
\begin{gathered}
\mathrm{CaBr}_{2}+\mathrm{H}_{2} \mathrm{O} \stackrel{750^{\circ} \mathrm{C}}{\longrightarrow} \mathrm{CaO}+2 \mathrm{HBr} \\
\mathrm{CaO}+\mathrm{Br}_{2} \stackrel{600^{\circ} \mathrm{C}}{\longrightarrow} \mathrm{CaBr}_{2}+1 / 2 \mathrm{O}_{2} \\
\mathrm{Fe}_{3} \mathrm{O}_{4}+8 \mathrm{HBr} \stackrel{300^{\circ} \mathrm{C}}{\longrightarrow} 3 \mathrm{FeBr}_{2}+4 \mathrm{H}_{2} \mathrm{O}+\mathrm{Br}_{2}
\end{gathered}
$$




$$
3 \mathrm{FeBr}_{2}+4 \mathrm{H}_{2} \mathrm{O} \stackrel{600^{\circ} \mathrm{C}}{\longrightarrow} \mathrm{Fe}_{3} \mathrm{O}_{4}+6 \mathrm{HBr}+\mathrm{H}_{2}
$$

on the account of salts or metal oxides in solid form, as "spherical pellets". Due to the $\mathrm{CaBr}_{2}$ high melting point, the efficiency of the hydrogen production process is of only $40 \%$.

$$
\begin{gathered}
\left(\mathrm{H}_{2} \mathrm{SO}_{4}\right)_{\mathrm{g}} \stackrel{700-1000^{\circ} \mathrm{C}}{\longrightarrow}\left(\mathrm{H}_{2} \mathrm{O}\right)_{\mathrm{g}}+\left(\mathrm{SO}_{3}\right)_{\mathrm{g}} \\
\left(\mathrm{SO}_{3}\right)_{\mathrm{g}} \stackrel{700-1000^{\circ} \mathrm{C}}{\longrightarrow}\left(\mathrm{SO}_{2}\right)_{\mathrm{g}}+1 / 2 \mathrm{O}_{2} \\
\left(\mathrm{SO}_{2}\right)_{\mathrm{g}}+\left(\mathrm{Br}_{2}\right)_{1}+\left(2 \mathrm{H}_{2} \mathrm{O}\right)_{1} \stackrel{\approx 100^{\circ} \mathrm{C}}{\longrightarrow}(2 \mathrm{HBr})_{\mathrm{g}}+\left(\mathrm{H}_{2} \mathrm{SO}_{4}\right)_{1} \\
(2 \mathrm{HBr})_{1} \stackrel{200^{\circ} \mathrm{C}}{\longrightarrow} \mathrm{H}_{2}+\mathrm{Br}_{2}
\end{gathered}
$$

d. The Mark-13 or the cycle of $\mathrm{H}_{2} \mathrm{SO}_{4}-\mathrm{Br}_{2}$, is described by the following chemical transformations:

$$
\begin{gathered}
\left(\mathrm{H}_{2} \mathrm{SO}_{4}\right)_{\mathrm{g}} \stackrel{700-1000^{\circ} \mathrm{C}}{\longrightarrow}\left(\mathrm{H}_{2} \mathrm{O}\right)_{\mathrm{g}}+\left(\mathrm{SO}_{3}\right)_{\mathrm{g}} \\
\left(\mathrm{SO}_{3}\right)_{\mathrm{g}} \stackrel{700-1000^{\circ} \mathrm{C}}{\longrightarrow}\left(\mathrm{SO}_{2}\right)_{\mathrm{g}}+1 / 2 \mathrm{O}_{2} \\
\left(\mathrm{SO}_{2}\right)_{\mathrm{g}}+\left(\mathrm{Br}_{2}\right)_{1}+\left(2 \mathrm{H}_{2} \mathrm{O}\right)_{1} \stackrel{\approx 100^{\circ} \mathrm{C}}{\longrightarrow}(2 \mathrm{HBr})_{\mathrm{g}}+\left(\mathrm{H}_{2} \mathrm{SO}_{4}\right)_{1} \\
(2 \mathrm{HBr})_{1} \stackrel{200^{\circ} \mathrm{C}}{\longrightarrow} \mathrm{H}_{2}+\mathrm{Br}_{2}
\end{gathered}
$$

Here hydrogen is released by decomposing electrolytic $\mathrm{HBr}$, with an efficiency of $37 \%$.

e. Metal-metal oxide cycle developed at PSI, Switzerland, schematically as follows:

$$
\begin{gathered}
\mathrm{M}_{\mathrm{m}} \mathrm{O}_{\mathrm{n}} \rightarrow \mathrm{M}_{\mathrm{m}} \mathrm{O}_{\mathrm{n}-\mathrm{x}}+\mathrm{x} / 2 \mathrm{O}_{2} \\
\mathrm{M}_{\mathrm{m}} \mathrm{O}_{\mathrm{n}-\mathrm{x}}+\mathrm{xH}_{2} \mathrm{O} \rightarrow \mathrm{M}_{\mathrm{m}} \mathrm{O}_{\mathrm{n}}+\mathrm{xH}_{2}
\end{gathered}
$$

If water splitting occurs at $650{ }^{\circ} \mathrm{C}$, the reduction of the metal oxide is at a temperature of $2000^{\circ} \mathrm{C}$. The research was done on the system: $\mathrm{Fe}_{3} \mathrm{O}_{4} / \mathrm{FeO} ; \mathrm{Mn}_{3} \mathrm{O}_{4} / \mathrm{MnO}, \mathrm{ZnO} / \mathrm{Zn}$; $\mathrm{Co}_{2} \mathrm{O}_{3} / \mathrm{CoO}$ or $\mathrm{MFe}_{2} \mathrm{O} 4$, where $\mathrm{M}=\mathrm{Cu}, \mathrm{Ni}, \mathrm{Co}, \mathrm{Mg}, \mathrm{Zn}$.

f. Thermochemical cycle methane- methanol - iodomethane was tested in South Korea and can be played as follows:

$$
\begin{gathered}
\mathrm{CH}_{4}+\mathrm{H}_{2} \mathrm{O} \rightleftharpoons \mathrm{CO}+3 \mathrm{H}_{2} \\
\mathrm{CO}+2 \mathrm{H}_{2} \rightleftharpoons \mathrm{CH}_{3} \mathrm{OH} \\
2 \mathrm{CH}_{3} \mathrm{OH}+\mathrm{I}_{2} \rightleftharpoons 2 \mathrm{CH}_{3} \mathrm{I}+\mathrm{H}_{2} \mathrm{O}+1 / 2 \mathrm{O}_{2} \\
2 \mathrm{CH}_{3} \mathrm{I}+\mathrm{H}_{2} \mathrm{O} \rightleftharpoons \mathrm{CH}_{3} \mathrm{OH}+\mathrm{CH}_{4}+\mathrm{I}_{2}
\end{gathered}
$$

Transformations occur at $150^{\circ} \mathrm{C}$ and a pressure of $1.2 \mathrm{MPa}$.

There are also known other hydrogen production processes based on thermochemical cycles, such as another one, HHLT and others. 
g. High-temperature electrolysis. Hydrogen can be produced by electrolysis of water vapor at $750-950{ }^{\circ} \mathrm{C}$, by the reactions:

$$
\begin{aligned}
& \mathrm{K}(-): 2 \mathrm{H}_{2} \mathrm{O}+4 \mathrm{e}^{-} \rightarrow 2 \mathrm{H}_{2}+2 \mathrm{O}^{2-} \\
& \mathrm{A}(+): \quad 2 \mathrm{O}^{2-} \rightarrow \mathrm{O}_{2}+4 \mathrm{e}^{-}
\end{aligned}
$$

\section{Radiolytic split of water molecules in several experimental conditions}

In this sense, it know a number of studies respecting the hydrogen obtaining by catalyzed decomposition of water under the influence of nuclear radiation emitted by some sources, including fission products recovered from spent nuclear fuel.

Thus, Maeda and co-workers have studied obtaining of molecular hydrogen by irradiation with $\gamma$ radiations of silicagels and metal oxides dispersed in water.

They found that a higher radiolytic yield was obtained in the silicagels case with pore diameter of about $2 \mathrm{~nm}$, and the most active area against water decomposition under the action of $\gamma$ radiation was the $\mathrm{SiO}_{2}$ dried at $100{ }^{\circ} \mathrm{C}$ (Maeda et al., 2005).

Yamamoto and collab. have used in their investigations nanoparticles of $\mathrm{TiO}_{2}$ and $\alpha-$ and $\beta$ $\mathrm{Al}_{2} \mathrm{O}_{3}$ noting that the radiolytic yield of molecular hydrogen production when irradiated with $\gamma$ radiation of aqueous solutions with $\alpha$ - and $\beta-\mathrm{Al}_{2} \mathrm{O}_{3}$ is 7-8 times higher than water irradiation without catalyst (Yamamoto et al., 1999)

Jung and collab. studied the effect of adding EDTA on the reaction of water radiolysis containing $\mathrm{TiO}_{2}$ and noted that the presence of this organic compound increased the radiolytic yield of molecular hydrogen (Jung et al.,2003).

Rotureau and collab. studied the obtaining molecular hydrogen from water radiolysis in presence of $\mathrm{SiO}_{2}$ and of mesoporous molecular sieves obtaining a value of radiolytic yield of molecular hydrogen $\mathrm{G}_{\mathrm{H} 2}=3$ (Rotureau et al. 2006).

Recently, Kazimi and Yildiz studied the obtaining of hydrogen through alternative nuclear energy, including radioactive wastes that result from nuclear plants (Yildiz \& Kazimi, 2006).

Brewer and colleagues have used complex supramolecular of ruthenium and rhodium in the study of water decomposition under the action of radiant energy (Brewer \& Elvington, 2006).

Masaki and Nakashima studied the gamma-irradiation of $\mathrm{Y}$ zeolites both in form $\mathrm{Na}(\mathrm{NaY})$ and form $\mathrm{H}(\mathrm{HY})$. Discussions on obtaining $\mathrm{H}$ and $\mathrm{H}_{2}$ were based on comparing values $\mathrm{G}_{\mathrm{H} 2}$

and $\mathrm{G}_{H}$ between systems NaY- and HY-water. They obtained higher values of radiolyitc yield of $\mathrm{H}_{2}$ due to energy transfer from zeolite to absorbed water (Nakashima \& Masaki, 1996).

The $\mathrm{G}\left(\mathrm{H}_{2}\right)$ values of $\mathrm{HY}$ system were 3 times higher than those of system $\mathrm{NaY}$.

Seino and co-workers observed that the nanoparticles of $\mathrm{TiO}_{2}$ and $\mathrm{Al}_{2} \mathrm{O}_{3}$ dispersed in water would lead to a significant increase of radiolytic yields of hydrogen to radiolytic yield of pure water. They also noted that radiolytic yield of hydrogen depends on gamma radiation dose absorbed and metal oxide particle size (Seino et al., 2001; Seino et al., 2001).

Yoshida and collab. proposed to get hydrogen by gamma irradiation of water in the presence of $\mathrm{Al}_{2} \mathrm{O}_{3}$ particles of different diameters. The maximum amount of hydrogen produced was $3.48 \mu \mathrm{mol} / \mathrm{cm}^{3}$ for water containing $\mathrm{Al}_{2} \mathrm{O}_{3}$ particles with diameter of $3 \mu \mathrm{m}$, value three times higher than the one obtained for the systems with pure water (Yoshida et 
al., 2007). Hydrogen produced from catalyzed reactions of water radiolysis was determined by gas chromatography.

Cecal and others (intended to obtain hydrogen through water radiolysis in the presence of solid catalysts, in different experimental conditions, under the action of gamma rays emitted by a source of $\mathrm{Co}^{60}$. The produced hydrogen was determined by a device specially adapted for mass spectrometer (Cecal et al., 2001; Cecal et al., 2003; Cecal et al., 2004). This study may be accomplished using as irradiation $\gamma$ source so called spent nuclear fuel elements extracted from nuclear plants as high level radioactive wastes, instead of the $\beta-\gamma$ Co-60 or Cs-137 radionuclides.

\section{Irradiation characteristics}

Qualitative and quantitative effects of phenomena suffered by substances after interaction with ionizing radiation are determined by the characteristics of the irradiation process.

Irradiation process is characterized by the following quantities (Arnikor, 1987; Ferradini \& Pucheault, 1983):

- radiation intensity,

- absorbed dose,

- absorbed dose rate,

- dose equivalent,

- linear energy transfer radiation (LET).

Radiation intensity: This feature expresses the amount of energy emitted by source, and expressed in $\mathrm{J} / \mathrm{s}$.

Absorbed dose, denoted $\mathrm{D}_{\mathrm{a}}$, represents the amount of energy transferred by incident radiation to unit mass of matter, energy absorbed by matter, respectively. In I.S absorbed dose is expressed as Gray $(G y)$ :

$1 \mathrm{~Gy}=1 \mathrm{~J} / \mathrm{kg}=6,24 \cdot 10^{13} \mathrm{eVg}^{-1}$.

Absorbed dose rate represents the energy received by the unit of mass per unit time. It is usually expressed in Gy/s, but there are also used $\mathrm{kGy} / \mathrm{h}, \mathrm{Mgy} / \mathrm{h}$, as well as $\mathrm{rad} / \mathrm{s}$, $\mathrm{rad} / \mathrm{min}, \mathrm{rad} /$ day if necessary.

Equivalent dose represents the radiation effect on the organism. Even at the same absorbed dose biological effects on living organisms may be different. This differential action is quantified by introducing a quality factor of incident radiation. As unit of measurement in I.S. there is used Sievert (Sv), which is defined as equivalent dose to the body (tissue) exposed to radiations with quality factor equal with unit when absorbed dose is $1 \mathrm{~Gy}$.

$1 \mathrm{~Sv}=\mathrm{v} \times 1 \mathrm{~Gy}$, where:

$\mathrm{v}$ - coefficient which depends on radiation quality, for $\mathrm{X}$ or $\mathrm{\gamma}, \mathrm{v}=1$.

Linear energy transfer radiation (LET)

As a result of interaction with matter, electromagnetic radiations continuously lose energy, photon beam intensity gradually decreasing as they penetrate matter. The phenomenon is called linear energy transfer noted LET, and it is expressed quantitatively by the radiation energy loss per unit length, LET $=-\mathrm{dE} / \mathrm{dx}$, with the unit $\mathrm{keV} / \mu \mathrm{m}$.

Linear energy transfer should increase as the particle slows down towards the end of the journey so that much of the ionization and excitation produced by fast electrons is produced on the path of gamma radiation, where linear energy transfer value is much higher than average. 
With the linear energy transfer there can be characterized, by a number the "quality" of a radiation, not always describing the type of radiation and its energy.

\section{Water radiolysis}

\subsection{General considerations}

A permanent presence of water and ionizing radiation in nature, show the appearance of water radiolysis on Earth and outside it. Laboratory experiments and computer simulations of the processes induced by radiolysis relate to radioactive action of $40 \mathrm{~K}$ in the ocean 3800 $\mathrm{Ma}(1 \mathrm{Ma}=1000000$ years ago) and natural radiation from the groundwater nuclear reactor of the Earth in its infancy.

Radiation-induced decomposition of water molecules, water radiolysis, is carefully studied for several authors, as Debiern, Marie Sklodowska Curie, O. Fricke, J. Franck, J. Weiss, Hart, Boag using different experimental conditions.

\subsection{Mechanism of water radiolysis}

As a result of water radiolysis with a beam of high-energy radiation as $\gamma$ radiation or an accelerated electron beam, it occurs excitation and ionization of water molecules, phenomenon that leads to the formation of various ion species, radicals and new molecules - radical theory of water radiolysis (Belloni \&Mostafavi, 2001; Kiefer, 1989; Majer, 1982).

According radicals' theory, radiolysis of water flows in three distinct phases:

a. Physical stage

A few pico-seconds after irradiation it is discovered the occurrence of excited molecules, $\mathrm{H}_{2} \mathrm{O}^{*}$ and ionized $\mathrm{H}_{2} \mathrm{O}^{+}$as of secondary electrons with high kinetic energy:

$$
\stackrel{\mathrm{H}_{2} \mathrm{O} \stackrel{\mathrm{e}^{-}, \gamma}{\longrightarrow} \mathrm{H}_{2} \mathrm{O}^{*}}{\mathrm{H}_{2} \mathrm{O}^{*} \rightarrow \mathrm{H}_{2} \mathrm{O}+}
$$

Secondary electrons, Compton or photoelectric are fast slowed down and thermalised, after which they are promptly captured by water molecules, hydrating themselves, $\left(\mathrm{e}_{\mathrm{aq}}{ }^{-}\right)$. Highlighting the hydrated electron is of great importance in the development of radiation chemistry. Electron hydration corresponds to the stabilization phase through dipole of solvent molecules:

$$
\begin{gathered}
\text { e- }+\mathrm{H}_{2} \mathrm{O} \rightarrow \mathrm{e}_{\mathrm{aq}^{-}} \\
\text {e- }+\mathrm{H}_{2} \mathrm{O} \rightarrow \mathrm{H} .+\mathrm{OH}-
\end{gathered}
$$

At physico-chemical stage, which takes about $10^{-13} \mathrm{~s}$, absorbed energy is redistributed through interactions with other stable or excited molecules and ions by splitting olyatomic molecules or through ion-molecule reactions.

It is noticeable that ion-molecule reactions do not necessarily imply ionized molecule movement; interactions can take place in liquid and at a distance of order of several interatomic distances:

$$
\mathrm{H}_{2} \mathrm{O}^{*} \rightarrow \mathrm{H} .+. \mathrm{OH}
$$




$$
\mathrm{H}_{2} \mathrm{O}++\mathrm{H}_{2} \mathrm{O} \rightarrow \mathrm{H}_{3} \mathrm{O}++\mathrm{OH}
$$

Ionized molecule can be neutralized by an electron:

$$
\mathrm{H}_{3} \mathrm{O}++\mathrm{e}-\rightarrow \mathrm{H}_{3} \mathrm{O}
$$

which quickly dissociates:

$$
\begin{aligned}
& \mathrm{H}_{3} \mathrm{O} \rightarrow \mathrm{H}_{2} \mathrm{O}+\mathrm{H} . \\
& \mathrm{H}_{3} \mathrm{O} \rightarrow \mathrm{e}^{-}+\mathrm{H}_{3} \mathrm{O}+
\end{aligned}
$$

Formed radicals can combine with each other, forming molecules:

$$
\begin{gathered}
\mathrm{H} .+\mathrm{H} . \rightarrow \mathrm{H}_{2} \\
. \mathrm{OH}+. \mathrm{OH} \rightarrow \mathrm{H}_{2} \mathrm{O}_{2} \\
. \mathrm{OH}+\mathrm{H} . \rightarrow \mathrm{H}_{2} \mathrm{O} .
\end{gathered}
$$

Chemical stage, which takes about $10^{-10} \mathrm{~s}$ is the phase in which there occur reactions between species formed in previous steps: recombination between radicals, ions, molecules and free electrons:

$$
\begin{aligned}
& . \mathrm{OH}+\mathrm{H}_{2} \rightarrow \mathrm{H}_{2} \mathrm{O}+\mathrm{H} \text {. reaction that inhibits radiolytic decomposition water } \\
& \qquad \begin{array}{r}
\mathrm{H} .+\mathrm{H}_{2} \mathrm{O}_{2} \rightarrow \mathrm{H}_{2} \mathrm{O}+\mathrm{OH} . \\
\text { e- }+\mathrm{H}_{2} \mathrm{O}_{2} \rightarrow . \mathrm{OH}+\mathrm{HO}- \\
\mathrm{HO}_{2}+\mathrm{H} . \rightarrow \mathrm{H}_{2} \mathrm{O}_{2}
\end{array}
\end{aligned}
$$

reaction which allows to explain the increase concentration of $\mathrm{H}_{2} \mathrm{O}_{2}$.

Molecular oxygen is produced through the following reactions:

$$
\begin{aligned}
& \mathrm{OH}+\mathrm{H}_{2} \mathrm{O}_{2} \rightarrow \mathrm{HO}_{2}+\mathrm{H}_{2} \mathrm{O} \\
& \mathrm{HO}_{2}+\mathrm{HO}_{2} \cdot \rightarrow \mathrm{H}_{2} \mathrm{O}_{2}+\mathrm{O}_{2}
\end{aligned}
$$

In the presence of dissolved molecular oxygen reaction takes place:

$$
\mathrm{O}_{2}+\mathrm{H} . \rightarrow \mathrm{HO}_{2}
$$

Hydrated electron $\mathrm{e}_{\mathrm{aq}}{ }^{-}$has both properties:

$$
\begin{gathered}
\text { - reducing: e- }+\mathrm{H}_{2} \mathrm{O} \rightarrow \mathrm{H}+\mathrm{HO}- \\
\text { - and basic: } \mathrm{e}-+\mathrm{H}+\rightarrow \mathrm{H} .
\end{gathered}
$$

Therefore, a few nano-seconds after irradiation, in water there are present the following species ionics, radicalics and molecules:

$\mathrm{H}_{3} \mathrm{O}^{+}, \mathrm{HO}^{-}, \mathrm{H}^{-}, \mathrm{OH}, \mathrm{HO}_{2}, \mathrm{H}_{2}, \mathrm{O}_{2}, \mathrm{H}_{2} \mathrm{O}_{2}$, of which the following are stable: $\mathrm{H}_{2}, \mathrm{H}_{2} \mathrm{O}_{2}, \mathrm{H}_{3} \mathrm{O}^{+}$, and short-lived free radicals $\mathbf{e}_{\mathbf{a q}}, \mathbf{H} \cdot \mathbf{H}, \mathbf{O H}, \mathbf{H O}_{2}$. 
5.3 Physical and chemical properties of primary species formed in water radiolysis The properties of some primary species formed in water radiolysis are presented in Table 1.

\begin{tabular}{|c|c|c|c|}
\hline Property & $\mathrm{e}^{-} \mathrm{aq}$ & $\mathrm{H} \cdot$ & $\mathrm{OH}$ \\
\hline Absorption maximum(nm) & 720 & $<200$ & 225 \\
\hline$\varepsilon$, molar extinction coefficient, $(\mathrm{L} / \mathrm{mol} \cdot \mathrm{cm})$ & 19.000 & 1620 & 240 \\
$(720 \mathrm{~nm})$ & $(188 \mathrm{~nm})$ & $(240 \mathrm{~nm})$ \\
\hline Diffusion coefficient $\left(\mathrm{cm}^{2} \mathrm{~s}^{-1} \times 10^{5}\right)$ & 4.9 & 8 & 2.3 \\
\hline Mobility $\left(\mathrm{cm}^{2} \mathrm{~V}^{-1} \mathrm{~s}^{-1} \times 10^{3}\right)$ & 1.98 & - & - \\
\hline$\Delta$ H ionization, $\mathrm{kJ} / \mathrm{mol}$ & - & 9.6 & 11.9 \\
\hline Electrons affinity $(\mathrm{eV})$ & & 0.776 & 1.83 \\
\hline
\end{tabular}

Table 1. Properties of some primary products of water radiolysis.

1. The hydrated electron $e^{-}$aq, is present in system a few milliseconds in the most favorable case. The hydrated electron is considered as a chemical species with a very high reactivity being a very strong reductant; it attaches immediately to radicals molecules or to meet ions. The formed new product containing an extra electron is generally unstable and dissociates forming new radicals or ions in an unstable valence state. Except s block metals other metal, cations are reduced as following:

$$
\mathrm{Mn}+{ }_{\mathrm{aq}}+\mathrm{e}-{ }_{\mathrm{aq}} \rightarrow \mathrm{Mn}-1_{\mathrm{aq}}
$$

Anions $\mathrm{F}^{-}, \mathrm{Cl}^{-}, \mathrm{Br}^{-}, \mathrm{I}-\mathrm{CN}-\mathrm{CH}-\mathrm{O} \mathrm{CN}^{-}$, with complete electronic layers and oxoanions $\left(\mathrm{SO}_{4}\right)^{2-}$, $\left(\mathrm{PO}_{4}\right)^{3-},\left(\mathrm{ClO}_{4}\right)^{-},\left(\mathrm{CO}_{3}\right)^{2-}$ do not react with the hydrated electron.

Organic molecules, aliphatic hydrides, alcohols, ethers and amines practically do not react with e-aq, while aliphatic carbonyl compounds such as aldehydes and ketones present a high reactivity.

Redox potential of water has high value $\mathrm{E}^{\circ}\left(\mathrm{nH}_{2} \mathrm{O} / \mathrm{e}^{-}{ }_{\mathrm{aq}}\right)=-2.87 \mathrm{~V}$ and it is not annihilated by any other species present in the system except the hydrated electron $\left(\mathrm{e}^{-}\right.$aq) within dismutation processes.

$$
\mathrm{e}_{-\mathrm{aq}}+\mathrm{e}_{\mathrm{aq}} \rightarrow \mathrm{H}_{2}+2 \mathrm{HO}-
$$

\section{Hydrogen atom, $H$}

The hydrogen atom or atomic hydrogen is a strong reductant, almost as vigorously as the hydrated electron, with the standard potential $\mathrm{E}^{\circ}\left(\mathrm{H}_{3} \mathrm{O}^{+} / \mathrm{H} \cdot\right)=-2.3 \mathrm{~V}$, at $\mathrm{pH}=0$.

It can uproot hydrogen from a $\mathrm{C}-\mathrm{H}$ link from an organic compound to form $\mathrm{H}_{2}$. It may also be a supplement to a double link.

Radical HO .

Radical $\mathrm{HO} \cdot$ is a strong oxidant, extremely energetic with standard potential $\mathrm{E}^{0}\left(\mathrm{HO} \cdot \mathrm{H}_{2} \mathrm{O}\right)=$ $2.76 \mathrm{~V}$; it is a species considered very dangerous for living cells in radiobiology. Oxidant properties of radical $\mathrm{HO}$ - depend on the $\mathrm{pH}$ of the medium. It is considered that at $\mathrm{pH}>9$, the radical is completely dissociated:

$$
\text { HO. } \rightarrow \mathrm{H}++ \text { O- }
$$

Radicals $\mathrm{OH}$ may participate in reactions with various components of the system:

$$
\text { HO. }+\mathrm{H}++\mathrm{e}_{-\mathrm{aq}} \rightarrow \mathrm{H}_{2} \mathrm{O}
$$




$$
\begin{aligned}
& \mathrm{HO} .+\mathrm{H}_{2} \rightarrow \mathrm{H} .+\mathrm{H}_{2} \mathrm{O} \\
& \mathrm{CO}+\mathrm{HO} . \rightarrow \mathrm{CO}_{2}+\mathrm{H}
\end{aligned}
$$

Radical HO reacts with organic compounds as it follows:

- $\quad$ extracting a hydrogen atom;

- $\quad$ can addition to a double bond;

- $\quad$ oxidizes primary alcohols to aldehydes in aqueous solutions;

- $\quad$ oxidizes aldehydes to acids, acids from peroxoacids etc.

In favorable conditions it can strip an electron from one molecule to form a cation.

4. Radical $\mathrm{HO}_{2}$.

$\mathrm{HO}_{2}$ radicals are obtained by the reaction of $\mathrm{HO} \cdot$ With $\mathrm{H}_{2} \mathrm{O}_{2}$ in general on the radiation trajectory or, possibly, in mass solution, if there are no HO- Radical traps and, of course, with a considerable concentration of $\mathrm{H}_{2} \mathrm{O}_{2}$. In accordance with this, the yield of these radicals would be higher in the case of low specific ionization radiation. Indeed, it was found that when water radiolysis with a radiation of $210 \mathrm{Po}$, radiochemical yield of $\mathrm{HO}_{2}$. radicals is 0.23 , while at the $\gamma$ radiolysis $\mathrm{G}_{\mathrm{HO} 2}=0.02$. Also, $\mathrm{HO}_{2}$. radicals are obtained from radiolysis of aqueous solutions containing $\mathrm{O}_{2}$, according to the reaction:

$$
\text { H. }+\mathrm{O}_{2} \rightarrow \mathrm{HO}_{2}
$$

The presence of these radicals in aqueous solutions was highlighted both by indirect methods and direct methods. Indirectly, there was studied the variation of the conductivity of irradiated water containing $\mathrm{O}_{2}$, in which case it has been detected the presence of some intermediate products with a lifetime in excess of $0.1 \mathrm{~s}$ and was attributed to $\mathrm{O}_{2}^{-}$-ions radical, which could come from $\mathrm{HO}_{2}$. $\mathrm{HO}_{2}$. radicals were revealed by direct methods using pulse radiolysis of water containing $\mathrm{O}_{2}$.

Due to the complexity of the phenomenon taking place in a watery liquid system when it interacts with $\gamma$ radiations this methodology was used for many purposes. This way, a new practical method for obtaining the most diverse products appeared, known as radiolytic method.

Within the research required in this paper, the radiolytic method is used to obtain hydrogen in the presence of different catalysts, using high-activity nuclear radiation about $5 \times 10^{4} \mathrm{Ci}$, emitted by spent nuclear fuel or ${ }^{60} \mathrm{Co}$ sources, process studied by other researchers, too.

\subsection{Radiolytic yield}

Radiolytic yield concept was introduced in order to quantify the effect of radiation, i.e. in order to calculate the amount of products formed depending on the dose of radiation absorbed.

There can be distinguished:

- Ionic-yield, g, also called ion pair yield, which is the ratio between the number of equivalents turned, the number of molecules that interact and the number of the formed ions.

- Radiolytic yield, $\mathrm{G}$ is the number of molecules (M) transformed by an energy equivalent to $100 \mathrm{eV}$ absorbed

$$
\mathrm{G}=\frac{\mathrm{M}}{100 \mathrm{eV}}
$$


This definition does not conform to International System units.

A new definition expresses $G$ yield, as expressed in mol $\mathrm{J}-1$, equivalent to $9.65 \times 10^{6}$ molecules $/ 100 \mathrm{eV}$, so that the defined value can be converted in I.S. units through multiplication with the $0.36 \times 10^{-7}$ factor.

To determine the yield of radiolysis products there are considered the maximum yields of radiolytic decomposition of water in which:

- $\quad \mathrm{W}_{\mathrm{a}}$ - the average ionization potential of water in the gas phase $(30 \mathrm{eV})$;

- $\quad \mathrm{I}_{\mathrm{a}}$ - minimum ionization potential of water $(12.56 \mathrm{eV})$

- $\quad E_{a}$ - the minimum excitation potential of water molecules $(6.5 \mathrm{eV})$

$100 \mathrm{eV}$ absorbed will form 100 / Wa water molecules ionized.

Formation of an ion consumes excitation energy equal to $\left(\mathrm{W}_{\mathrm{a}}-\mathrm{I}_{\mathrm{a}}\right) \mathrm{eV}$, so, for $100 \mathrm{~W}$ a ions, at absorption of $100 \mathrm{eV}$ there results an excitation energy of $100 \mathrm{~W} \mathrm{a}\left(\mathrm{W}_{\mathrm{a}}-\mathrm{I}_{\mathrm{a}}\right) \mathrm{eV}$.

In this way, due to excitation, there will be radiolysed $100\left(W_{a}-I_{a}\right) W_{a} E_{a}=$ water molecules.

$$
\mathrm{G}_{\mathrm{a}}=\frac{100}{\mathrm{~W}_{\mathrm{a}}}+\frac{100\left(\mathrm{~W}_{\mathrm{a}}-\mathrm{I}_{\mathrm{a}}\right)}{\mathrm{W}_{\mathrm{a}} \mathrm{I}_{\mathrm{a}}}=\frac{100}{\mathrm{~W}_{\mathrm{a}}}\left[1+\frac{\mathrm{W}_{\mathrm{a}}-\mathrm{I}_{\mathrm{a}}}{\mathrm{E}_{\mathrm{a}}}\right] \text { molecules } / 100 \mathrm{eV}
$$

$\mathrm{G}_{\mathrm{a} \max }=12$ molecules $100 \mathrm{eV}$.

In liquid phase $\mathrm{G}_{\mathrm{a} \text { max }}$ is approximately two times smaller.

In neutral aqueous solutions deaerated and irradiated with gamma radiation from a ${ }^{60} \mathrm{Co}$ source, the primary yield for radicals and molecules, in $\mu \mathrm{mol}$ and atoms $100 \mathrm{eV}$ is shown in Table 2.

On the other hand, (Majer, 1982) radiolytic yield depends not only on the concentration $\left(C_{x}\right)$ of the transformed reactant or on the reaction product occurred, but also on the irradiation time $(t)$ with nuclear radiations having a rate dose $(D)$ :

$$
G_{X}=\frac{C_{X} \cdot N}{D \cdot t} \cdot 100
$$

$\mathrm{N}$ - Avogadro's number. Product $\mathrm{D} t=\mathrm{D}_{\mathrm{a}}$ is dose of absorbed energy, expressed in $\mathrm{eV} \cdot \mathrm{L}$ 1 mol-1. Radiolytic yield for different species stable or unstable: $\mathrm{H} ; \mathrm{HO}$; $\mathrm{HO}_{2}, \mathrm{H}_{2} \mathrm{O}_{2}, \mathrm{H}_{2}$, etc. is determined from the slope obtaining by plotting the previous relation (3) in coordinates $C_{x}=f\left(D_{a}\right)$.

The concentrations of chemical species encountered by primary irradiation $(\mathrm{H} \cdot$ and $\mathrm{HO} \cdot)$ or subsequent reactions $\left(\mathrm{HO}_{2}, \mathrm{H}_{2} \mathrm{O}_{2}, \mathrm{H}_{2}\right.$..) can be determined by physico-chemical methods such as: electron paramagnetic resonance (EPR), the pulse radiolysis, spectrophotometry etc. or from measurements of luminescence or radical capture.

Henglein proposed a similar formula to determine the radiolytic yield (Heinglein et al., 1969):

$$
G_{x}=\frac{C_{x} \cdot N \cdot 100}{D_{a} \cdot g \cdot 1000 \cdot 6.24 \cdot 10^{13}}=\frac{C_{x}}{D_{a} \cdot g} \cdot 9.66 \cdot 10^{8}, \mathrm{~mol} \cdot J-1
$$

Given the sequence of chemical reactions initiated by nuclear radiation:

$$
\mathrm{H}_{2} \mathrm{O}++\mathrm{H}_{2} \mathrm{O}-\rightarrow 2 \mathrm{H}_{2} \mathrm{O}^{*} \rightarrow 2 \mathrm{H}+2 \mathrm{HO}
$$




$$
\begin{gathered}
\longrightarrow \mathrm{H}_{2} \mathrm{O} \rightarrow \mathrm{H}_{2} \mathrm{O}^{*} \rightarrow \mathrm{H}+\mathrm{HO} \\
\mathrm{H}+\mathrm{H} \cdot \rightarrow \mathrm{H}_{2} \\
\mathrm{HO} \cdot+\mathrm{HO} \cdot \rightarrow \mathrm{H}_{2} \mathrm{O}+\mathrm{O} \\
\mathrm{HO} \cdot+\mathrm{HO} \cdot \rightarrow \mathrm{HO}_{2} \cdot \mathrm{H} \cdot \\
\mathrm{HO} \cdot+\mathrm{HO} \cdot \rightarrow \mathrm{H}_{2} \mathrm{O}_{2} \\
\mathrm{H}_{2} \mathrm{O}_{2}+\mathrm{HO} \cdot \rightarrow \mathrm{H}_{2} \mathrm{O}+\mathrm{HO}_{2} \\
\mathrm{H} \cdot+\mathrm{O}_{2} \rightarrow \mathrm{HO}_{2}
\end{gathered}
$$

It appears that the formation of a single pair of radicals $\mathrm{H} \cdot$ and $\mathrm{HO} \cdot($ reaction 1.30) decomposes with a single molecule of water. For the appearance of molecular hydrogen (the

\begin{tabular}{|c|c|c|c|c|c|c|c|}
\hline $\begin{array}{l}\text { Type of } \gamma \\
\text { radiation, } \\
0.1-10 \mathrm{MeV}\end{array}$ & $\begin{array}{c}\text { Linear } \\
\text { energy } \\
\text { transfer, } \\
\mathrm{keV} / \mu \mathrm{m}\end{array}$ & $\begin{array}{c}G_{\left(H_{2}\right)} \\
\mu \mathrm{mol} / \mathrm{J}\end{array}$ & $\begin{array}{c}G_{\left(\mathrm{H}_{2} \mathrm{O}_{2}\right)} \\
\mu \mathrm{mol} / \mathrm{J}\end{array}$ & $\begin{array}{c}G_{\left(e_{a q}\right)} \\
\mu \mathrm{mol} / \mathrm{J}\end{array}$ & $\begin{array}{c}G_{(H)} \\
\mu \mathrm{mol} / \mathrm{J}\end{array}$ & $\begin{array}{c}G_{(H O)} \\
\mu \mathrm{mol} / \mathrm{J}\end{array}$ & $\begin{array}{c}G_{\left(\mathrm{HO}_{2}\right)} \\
\mu \mathrm{mol} / \mathrm{J}\end{array}$ \\
\hline $\mathrm{pH}=3-11$ & 0.20 & 0.047 & 0.073 & 0.28 & 0.06 & 0.28 & 0.0027 \\
\hline \multirow[t]{2}{*}{$\mathrm{pH}=0.46$} & 0.20 & 0.041 & 0.081 & 0 & 0.378 & 0.301 & 0.0008 \\
\hline & & $\begin{array}{c}G_{\left(H_{2}\right)} \\
\text { at/ } 100 \mathrm{eV}\end{array}$ & $\begin{array}{c}G_{\left(\mathrm{H}_{2} \mathrm{O}_{2}\right)} \text { at } \\
/ 100 \mathrm{eV}\end{array}$ & $\begin{array}{c}G_{\left(e_{a q}\right)} \\
\text { at } / 100 \mathrm{eV}\end{array}$ & $\begin{array}{c}G_{(H)} \\
\text { at } / 100 \mathrm{eV}\end{array}$ & $\begin{array}{c}G_{(\mathrm{HO})} \\
\text { at } / 100 \mathrm{eV}\end{array}$ & $\begin{array}{c}G_{\left(\mathrm{HO}_{2}\right)} \\
\text { at } / 100 \mathrm{eV}\end{array}$ \\
\hline $\mathrm{pH}=3-11$ & 0.20 & 0.45 & 0.704 & 2.7 & 0.579 & 2.79 & 0.026005 \\
\hline $\mathrm{pH}=0.46$ & 0.20 & 0.39 & 0.78 & 0 & 3.64 & 2.9 & 0.0077 \\
\hline
\end{tabular}
stable product of radiolysis - reaction 1.31) two molecules of water will decompose, while producing a molecule of hydrogen peroxide (as a stable product) needed also two molecules of water (reaction 1.34).

The balance equation becomes:

$$
\mathrm{G}_{\left(-\mathrm{H}_{2} \mathrm{O}\right)}=\mathrm{G}_{(\mathrm{H} \times)}+2 \mathrm{G}_{\left(\mathrm{H}_{2}\right)}=\mathrm{G}_{(\mathrm{HO} \times)}+2 \mathrm{G}_{\left(\mathrm{H}_{2} \mathrm{O}_{2}\right)}+3 \mathrm{G}_{\left(\mathrm{HO}_{2} \times\right)}
$$

Table 2. Primary radiolytic yield values for ions and radicals from irradiated water at $25^{\circ} \mathrm{C}$.

The values from Table 2 show that the prevalent species are the solvated electron and the $\mathrm{OH}$ radical.

In the range of $\mathrm{pH}=3-12$, forming efficiency of primary species does not vary, but the radicals may be located in various chemical forms depending on $\mathrm{pH}$. 
These existing acid-base equilibria are characterized by constant acidity / basicity.

For example, at $\mathrm{pH}=7, \mathrm{HO}_{2}$, over $99 \%$ of the radicals formed according to the reaction:

$$
\mathrm{HO}_{2} \rightarrow \mathrm{H}++\mathrm{O}_{2-}
$$

are represented as oxide, $\mathrm{O}^{2}$-.

Table 3 shows acidic and basic forms of data and pK radicals.

\begin{tabular}{|c|c|c|c|}
\hline Radicals & Acidic form & Basic form & $\mathrm{pK}$ \\
\hline $\mathrm{H} \cdot$ & $\mathrm{H} \cdot$ & $\mathrm{e}^{-}{ }_{\mathrm{aq}}$ & 9.6 \\
\hline $\mathrm{e}^{-} \mathrm{aq}$ & $\mathrm{H} \cdot$ & $\mathrm{e}^{-}{ }_{\mathrm{aq}}$ & 9.6 \\
\hline $\mathrm{OH}$ & $\mathrm{OH}$ & $\mathrm{O}^{-}$ & 11.9 \\
\hline $\mathrm{HO}_{2} \cdot$ & $\mathrm{HO}_{2} \cdot$ & $\mathrm{O}_{2^{-}}$ & 4.8 \\
\hline
\end{tabular}

Table 3. pK values for acidic and basic forms of the radicals formed from water radiolysis.

Among the primary species formed in the radiolysis reactions, important are the reactions of free radicals and radical solution.

Free radical reactions: the most species of free radicals are unstable in solution and hence highly reactive. They quickly recombine with each other to form stable molecular products. As shown above, most of the molecular species formed during irradiation are formed by recombination of free radicals:

$$
\begin{gathered}
\text { H. }+ \text { H. } \rightarrow \mathrm{H}_{2} \\
. \mathrm{OH}+. \mathrm{OH} \rightarrow \mathrm{H}_{2} \mathrm{O}_{2}
\end{gathered}
$$

Radical reactions take place, generally, in solution and have fast kinetics.

Free radicals can react with molecules to form other molecules or free radicals, according to the general equation:

$$
\text { Radical } 1+\text { Molecule1 } \rightarrow \text { Radical } 2+\text { Molecule } 2
$$

\subsection{Considerations on the radiolytic yield $\left(\mathrm{G}_{\mathrm{H} 2}\right)$}

Mass spectrometer was calibrated before measurements of irradiated samples on the basis of resulted hydrogen in a total chemical reaction:

$$
\mathrm{Zn}+2 \mathrm{HCl}_{\text {dil }} \rightarrow \mathrm{ZnCl}_{2}+\mathrm{H}_{2}
$$

From $1.08 \mathrm{~g} \mathrm{Zn} \rightarrow 0.01 \mathrm{~mol} \mathrm{H}_{2} \rightarrow$ the spectrogram corresponds in the table to a bit of 1.58 $\cdot 10^{6}$ a.u. intensity (for anionic and cationic clays) and $2.68 \cdot 10^{7}$ a.u. for the species with mass number 2, respectively.

Schematic diagram of the measurements performed is given below:

\section{Sample $\rightarrow$ Mass spectrometer $\rightarrow \mathrm{PC} \rightarrow$ Mass spectrogram}

Before each measurement, to avoid any contamination of samples by chemical species remaining from the previous sample, the mass spectrometer was ensured a vacuum of 2.10-6 Torr. Mass spectrogram was recorded by a computer in coordinates peak intensity $=\mathrm{f}$ (Mass number), and recorded data were processed with chemistry program Origin 7.1. 
It is well known that radiolysis of water through two stages, primary and secondary, leads to the formation of various chemical species such as: $\mathrm{H}_{2}, \mathrm{O}_{2}, \mathrm{H}_{2} \mathrm{O}_{2}, \mathrm{HO} \cdot, \mathrm{O}, \mathrm{HO}_{2}{ }^{\circ}$, etc. through a series of reactions with excited species, ionized and free radicals:

$$
\begin{aligned}
& \leadsto \mathrm{H}_{2} \mathrm{O} \rightarrow \mathrm{H}_{2} \mathrm{O}^{*} \rightarrow \mathrm{H} \text {. }+\mathrm{HO} \text {. } \\
& \leadsto \mathrm{H}_{2} \mathrm{O} \rightarrow \mathrm{H}_{2} \mathrm{O}++\mathrm{e}- \\
& \mathrm{H}_{2} \mathrm{O}+\mathrm{e}-\longrightarrow \mathrm{H}_{2} \mathrm{O}- \\
& \mathrm{H}_{2} \mathrm{O}++\mathrm{H}_{2} \mathrm{O}-\rightarrow 2 \mathrm{H}_{2} \mathrm{O}^{*} \\
& \text { H. }+ \text { H. } \rightarrow \mathrm{H}_{2} \\
& \text { HO. }+ \text { HO. } \rightarrow \mathrm{HO}_{2},+\mathrm{H} \text {. } \\
& \text { H. }+\mathrm{O} \rightarrow \mathrm{HO} \text {. } \\
& \text { HO. }+\mathrm{HO}_{2} . \rightarrow \mathrm{H}_{2} \mathrm{O}_{2}+\mathrm{O} \text {. }
\end{aligned}
$$

Considering that energy transfer from the catalyst to water molecules plays an important role in the decomposition of water in the presence of catalyst, radiolysis can be expressed as:

$$
\begin{gathered}
X X^{*}(\text { activated state }) \\
\left.\mathrm{X}^{*}+\mathrm{H}_{2} \mathrm{O} \rightarrow\left[\mathrm{H}_{2} \mathrm{O} . \mathrm{X}\right]^{*} \text { (activated complex }\right) \\
{\left[\mathrm{H}_{2} \mathrm{O} . \mathrm{X}\right]^{*} \rightarrow \mathrm{H} .+\mathrm{HO} .+\mathrm{X}+\mathrm{hv}}
\end{gathered}
$$

To calculate the radiolytic yield of hydrogen, Henglein's formula:

$$
\mathrm{G}=\frac{\mathrm{c} \cdot \mathrm{N}_{\mathrm{A}} \cdot 100}{\mathrm{D}_{\mathrm{a}} \cdot \rho \cdot 1000 \cdot 6.25 .10^{13}}=\frac{c}{\mathrm{D}_{\mathrm{a}} \cdot \rho} \times 9.66 .10^{8}
$$

where:

$\mathrm{D}_{\mathrm{a}}$ - absorbed dose Gy (1Ykg or 6.24. $10^{13} \mathrm{eV} / \mathrm{g}$ ) representing the product of dose debit (D) and irradiation time $(\mathrm{t})$

$\rho$ - density of irradiated material $\left(\mathrm{g} / \mathrm{cm}^{3}\right)$

$\mathrm{N}_{\mathrm{A}}$-Avogadro number

Considering that:

$$
\mathrm{c}=\mathrm{b} \cdot \frac{\mathrm{I}_{\mathrm{x}}}{\mathrm{I}_{\mathrm{et}}}
$$

Radiolytic yield of hydrogen resulted from radiolysis are calculated with the expression derived:

$$
\mathrm{G}_{\mathrm{H}_{2}}=\frac{\mathrm{b} \cdot \mathrm{I}_{\mathrm{x}}}{\mathrm{D} \cdot \mathrm{t} \cdot \rho \cdot \mathrm{I}_{\mathrm{et}}} \cdot 9.66 \times 10^{6}
$$


where:

$$
D \cdot t=D_{a}-\text { is absorbed dose in Gy }
$$

$\rho$ - density of irradiated material $\left(\mathrm{g} / \mathrm{cm}^{3}\right)$

$b$ - amount of hydrogen resulting from the spectrometer calibration $\left(\mathrm{mol} \mathrm{H}_{2} / 1 \mathrm{~kg} \mathrm{H}_{2} \mathrm{O}\right)$

$\mathrm{I}_{\mathrm{et}}$ - intensity peak corresponding to molecular hydrogen from the reaction mass spectrometer calibration

$I_{x}$ - intensity peak corresponding to molecular hydrogen from the reaction of catalyzed radiolysis

Radiolytic yield was calculated for:

$\mathrm{b}=1.53 \mathrm{~mol} \mathrm{H}_{2} / 1 \mathrm{~kg} \mathrm{H} \mathrm{O}$, Iet $=2.68 \cdot 10^{7}$ arbitrary unit (cationic and anionic clays)

$\mathrm{b}=1.556 \mathrm{~mol} \mathrm{H}_{2} / 1 \mathrm{~kg} \mathrm{H} \mathrm{H}_{2} \mathrm{O}$, Iet $=1.58 \cdot 10^{7}$ arbitrary unit (catalyst with and double perovskitic oxides)

In mass spectrograms there have identified a number of species $\left(\mathrm{H}_{2}, \mathrm{O}_{2}, \mathrm{H}_{2} \mathrm{O}_{2}, \mathrm{HO} \cdot\right.$, O, $\mathrm{HO}_{2}{ }^{\circ}$ ), but radiolytic yield was established only for molecular hydrogen, which is a stable product of radiolysis. The other identified species $\left(\mathrm{HO} \cdot \mathrm{HO}_{2} \cdot \ldots\right)$ may occur in the ionization source mass spectrometer from the decomposition of molecules of water (as vapor), whereas as free radicals, disappear immediately.

\section{Experimental part}

In order to study the catalyzed radiolysis of water under the action of nuclear radiation, with hydrogen release, there were used two types of catalysts:

a. Clays.

In this case natural anionic clays have been used, such as: $\left(\mathrm{MgZn}_{2} \mathrm{Al}, \mathrm{Zn}_{2} \mathrm{Al}, \mathrm{Zn}_{2} \mathrm{CuAl}\right.$, $\mathrm{Mg}_{2} \mathrm{Al}$ ) and cationic $\mathrm{R}_{1}$ and $\mathrm{C}_{1}$ pillared with: $\mathrm{Cr}, \mathrm{Fe}, \mathrm{Al}$ and $\mathrm{Ti}$.

Raw clay $\left(\mathrm{R}_{1}, \mathrm{C}_{1}\right)$ have a complex mineralogical composition: $\mathrm{SiO}_{2}-69.61 \%, \mathrm{Al}_{2} \mathrm{O}_{3}-19.7 \%$, $\mathrm{MgO}-2.41 \%, \mathrm{Fe}_{2} \mathrm{O}_{3}-1.27 \%, \mathrm{Na}_{2} \mathrm{O}-1.31 \%, \mathrm{~K}_{2} \mathrm{O}-0.18 \%$ etc. The cation exchange capacity (CEC) of $82 \mathrm{mEq} / 100 \mathrm{~g}$ clay was determined with ammonium acetate, and the specific surface area is between $140-142 \mathrm{~m}^{2} / \mathrm{g}$.

At first there were prepared clays of the type $\mathrm{C}_{1}-\mathrm{Na}$ and $\mathrm{R}_{1}-\mathrm{Na}$ by cations exchanges naturally present, by dispersing those raw solid mass skins in a solution of $1 \mathrm{M} \mathrm{NaCl}$ at a temperature of $22^{\circ} \mathrm{C}$ and a contact time of 12 hours.

After that, the solid clay was separated by centrifugation as $\mathrm{C}_{1}-\mathrm{Na}$ or $\mathrm{R}_{1}-\mathrm{Na}$ of the remaining solid solution and dried at $110^{\circ} \mathrm{C}$. Clay particle size range was 0.2-0.8 mm (Van Olphen, 1963).

To obtain a microporous material with increasing interlamelare space and volume of pore, was performed Keggin inserting of the polications $\mathrm{Al}_{13^{7+}}$ between the layers of clay, resulting in pillared samples $\left(\mathrm{C}_{1}-\mathrm{Al}\right.$ and $\left.\mathrm{R}_{1}-\mathrm{Al}\right)$ with a specific surface of $280 \mathrm{~m}^{2} / \mathrm{g}$ and 320 $\mathrm{m}^{2} / \mathrm{g}$, respectively. Pillars of the cationic clays $\mathrm{C}_{1}-\mathrm{Na}$ and $\mathrm{R}_{1}-\mathrm{Na}$ with other cations were obtained by ion exchange Na- $\mathrm{M}^{\mathrm{n}+}$ where $\mathrm{M}^{\mathrm{n}+}$ is $\mathrm{Cr}^{3+}, \mathrm{Fe}^{3+}$ and $\mathrm{Ti}^{2+}$ (Asaftei et al., 2002; Popovici et al., 2006).

b. Site zeolites and mesoporous silica MCM-41.

The $\mathrm{Pt}^{2+}-\mathrm{ZSM}-5$ samples with different $\mathrm{SiO}_{2} / \mathrm{Al}_{2} \mathrm{O}_{3}$ ratios were prepared by ion exchange: $\mathrm{H}^{+}-$ ZSM-5-Pt' ${ }^{2+}$ in a solution of $\mathrm{H}_{2} \mathrm{PtCl}_{6}(10-3 \mathrm{M})$ at a temperature of $22^{\circ} \mathrm{C}$ and at a time 10 contact hours. Afterwards, the zeolitic precipitate was washed with distilled water and dried $110^{\circ} \mathrm{C}$. Platinum content was $1-2 \%$. The same process was applied to $\mathrm{NH}_{4}-\mathrm{ZSM}-5$. 
In order to prepare mesoporous silica MCM-41, there was made a mixture of: $27.3 \% \mathrm{SiO} 2$ and $10.8 \% \mathrm{NaOH}$, hexadecyl-trimethyl ammonium bromide, $\mathrm{C}_{16} \mathrm{H}_{33} \mathrm{~N}\left(\mathrm{CH}_{3}\right)_{3} \mathrm{Br}$ and $\mathrm{H}_{2} \mathrm{SO}_{4}(95 \%)$,

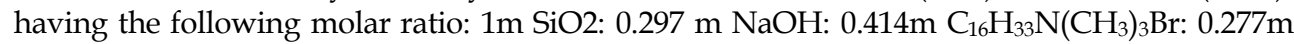
$\mathrm{H}_{2} \mathrm{SO}_{4}: 82.54 \mathrm{~m} \mathrm{H}_{2} \mathrm{O}$. After a contact time of 30 minutes, there has been obtain a gel which was then placed in an autoclave at $105^{\circ} \mathrm{C}$ for 48 hours. After that, the resulting solid product was washed and dried at room temperature (Mastalir et al., 2008; Zholobenko et al., 1997).

The experiments proceeded as it follows (Cecal et al., 2008; Hauta et al., 2009): different amounts of each catalyst were weighed and introduced in $50 \mathrm{ml}$ bottles, over which $30 \mathrm{ml}$ distilled water were added. Then the glass vials were sealed with rubber cork, paraphyned outside and subjected to various doses of radiation energy. The stable radiolysis product, $\mathrm{H}_{2}$, resulted in the above reactive systems, was determined quantitatively by a mass spectrometer, previously calibrated. The relationship between the irradiated sample and mass spectrometer was performed with a special device, which had at one end a chromatographic syringe needle that pierced the rubber stopper.

The obtained experimental results are represented in the following figures:

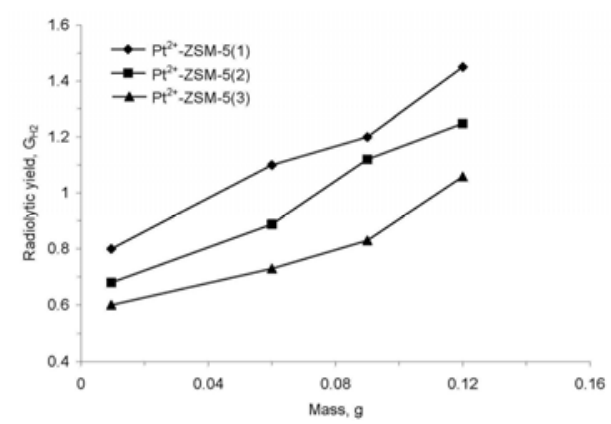

a.

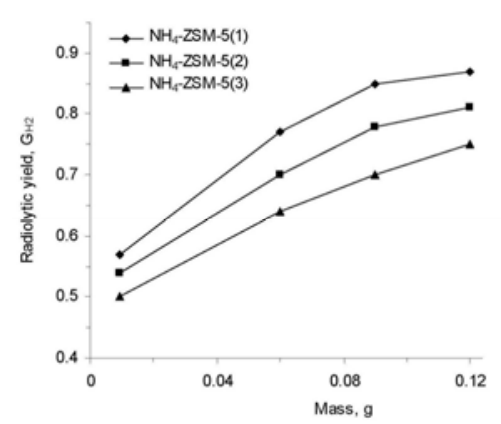

b.

Fig. 1. Plots of radiolytic yield vs catalyst mass for a) $\mathrm{Pt}^{2+}-\mathrm{ZSM}-5$ and b) $\mathrm{NH}_{4}-\mathrm{ZSM}-5$ with different $\mathrm{SiO}_{2} / \mathrm{Al}_{2} \mathrm{O}_{3}$ ratios $\mathrm{SiO}_{2} / \mathrm{Al}_{2} \mathrm{O}_{3}=140$, (2) $\mathrm{SiO}_{2} / \mathrm{Al}_{2} \mathrm{O}_{3}=80$, (3) $\mathrm{SiO}_{2} / \mathrm{Al}_{2} \mathrm{O}_{3}=15$.

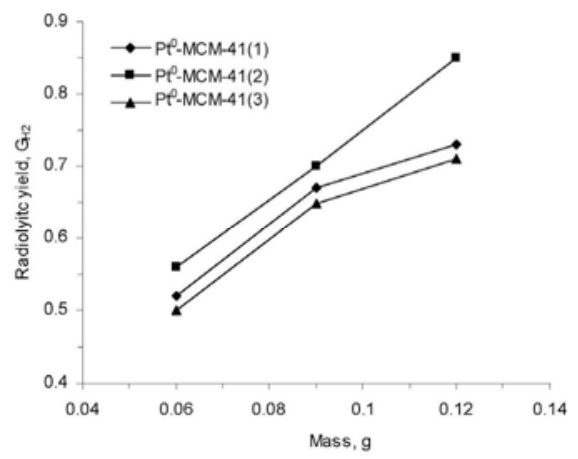

Fig. 2. Plots of radiolytic yield vs. catalyst mass for $\mathrm{Pt}^{0}-\mathrm{MCM}-41$ impregnated for 1 ) short temps 2) long temps, 3) before irradiation. 


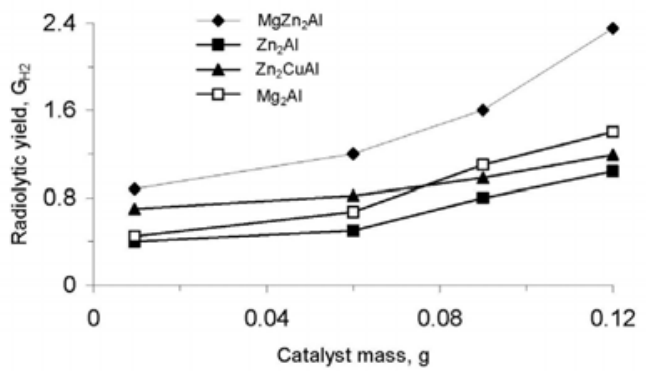

3.1

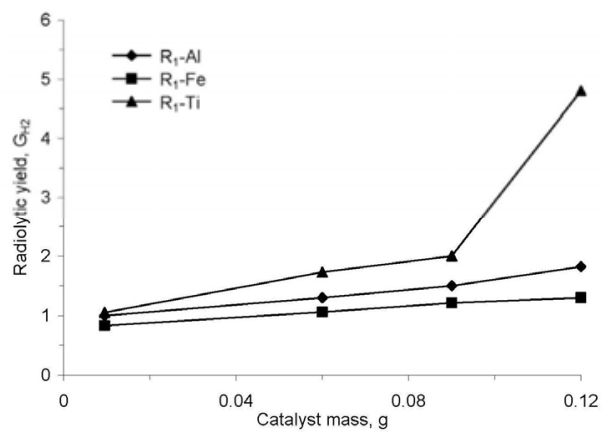

3.2

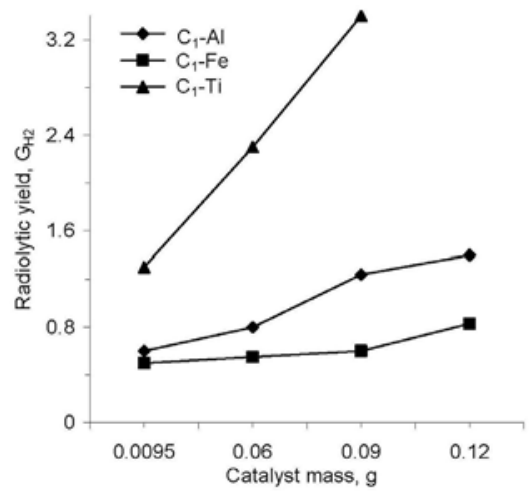

3.3

Fig. 3. Dependence of radiolytic yield of molecular hydrogen on the catalyst amounts for: (3.1) anionic clays; (3.2) $\mathrm{R}_{1}$-clays and (3.3) $\mathrm{C}_{1}$-clays. 


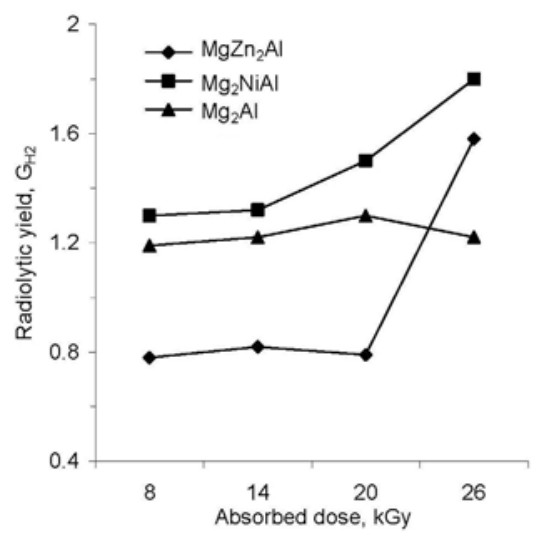

4.1

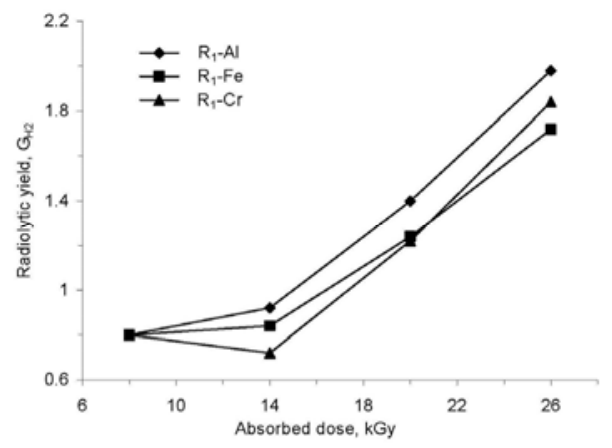

4.2

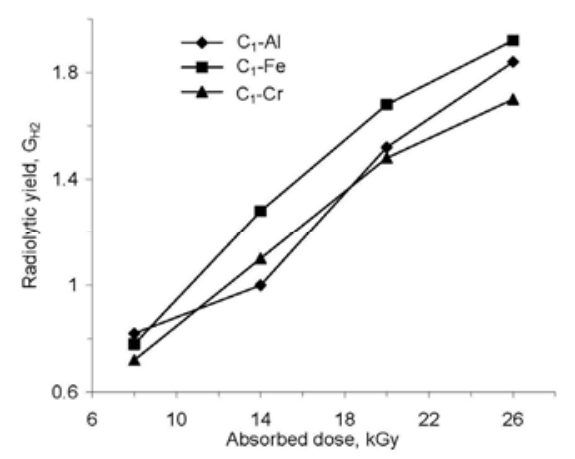

4.3

Fig. 4. Variation of radiolytic yield $\left(\mathrm{G}_{\mathrm{H} 2}\right)$ vs. absorbed dose for: (4.1) anionic clays, (4.2) $\mathrm{R}_{1}$ clays and (4.3) $\mathrm{C}_{1}$-clays. 


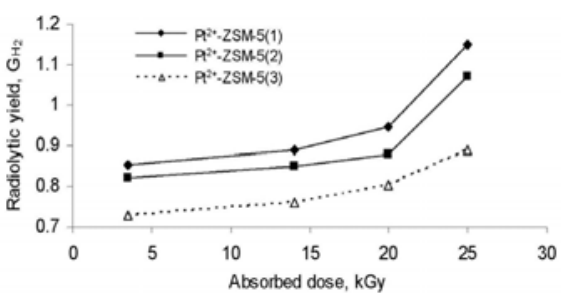

a.

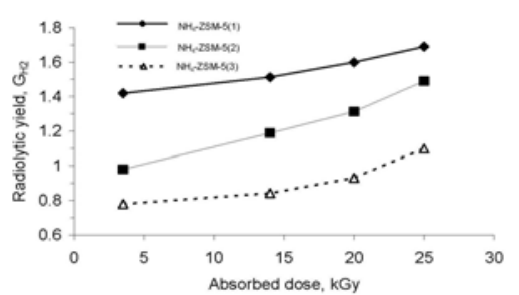

b.

Fig. 5. Plots of radiolytic yield vs. absorbed dose for: a) Pt ${ }^{2+}-\mathrm{ZSM}-5$ and b) $\mathrm{NH}_{4}-\mathrm{ZSM}-5$ with different $\mathrm{SiO}_{2} / \mathrm{Al}_{2} \mathrm{O}_{3}$ ratios (1) $\mathrm{SiO}_{2} / \mathrm{Al}_{2} \mathrm{O}_{3}=140$, (2) $\mathrm{SiO}_{2} / \mathrm{Al}_{2} \mathrm{O}_{3}=80$, (3) $\mathrm{SiO}_{2} / \mathrm{Al}_{2} \mathrm{O}_{3}=15$.

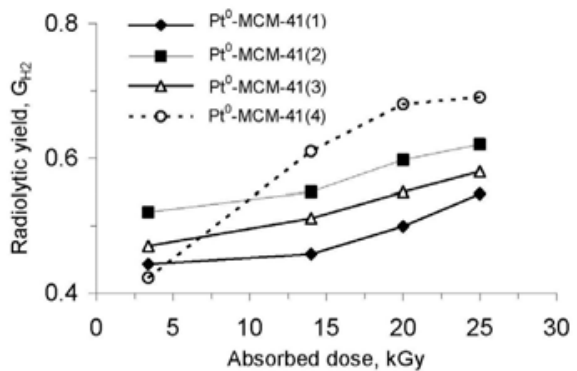

Fig. 6. Plots of radiolytic yield vs. absorbed dose for: a) $\mathrm{Pt}^{0}-\mathrm{MCM}-41$ impregnated samples for 1) short temps 2) long temps, 3) before irradiation, 4) after irradiation.

It is worth mentioning that the release of hydrogen was obtained only in the catalyst samples, previously subjected to irradiation with $\gamma$ radiations.

Explanations of the catalytic effects could be: the catalytic role of clay could be explained by facilitating the appearance of intermediate structures.

In the case of clays studied as catalysts in water radiolysis, it can be considered that in active status, the catalyst creates a structural availability so that dipole water molecules can penetrate its pores.

In this excited configuration of the catalyst, water molecules are subjected to Coulomb forces of attraction-repulsion of the ionic species in the clay structure.

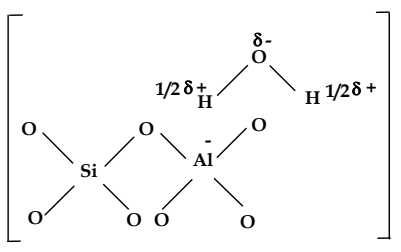

Under the action of gamma radiation, $\mathrm{H}-\mathrm{OH}$ bonds in water molecules adsorbed on the catalyst surface will be easier to split towards non-adsorbed water molecules.

It has been noticed an increasing amount of hydrogen resulted from water radiolysis in the presence of clays in comparison with the reference sample, irradiated under the same experimental conditions. In the case of pillared clays, greater efficiency in the decomposition of water have the pillared with Ti.. Pillared clays $\mathrm{R}_{1}$-metal had an important catalytic effect 
towards $\mathrm{C}_{1}$-metal, probably due to $\mathrm{SiO}_{2} / \mathrm{Al}_{2} \mathrm{O}_{3}$ different ratio and the presence of $3 \mathrm{~d}$ series microelements. Ionic species in the composition of clay acts as Coulomb attraction-repulsion forces on the dipole water molecules, facilitating $\mathrm{H}-\mathrm{OH}$ bonds break under the action of nuclear radiation.

In the case of zeolites, through the interaction of nuclear radiation on the surface, there might appear "charge carriers" e- and goals ${ }^{+}$, namely:

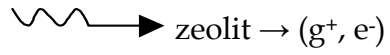

Water molecules can be broken down as it follows:

$$
\begin{gathered}
\mathrm{e}^{+}+\stackrel{\text { O }}{\mathrm{e}_{\mathrm{H}}^{-}} \stackrel{\mathrm{H}}{\longrightarrow} \rightarrow \mathrm{H}_{2} \mathrm{O}^{+} \longrightarrow \mathrm{H}^{+}+\mathrm{HO} \\
\mathrm{HO} \cdot+\mathrm{HO} \cdot \rightarrow \mathrm{H}_{2} \mathrm{O}+\mathrm{O} \\
\mathrm{O}+\mathrm{O} \rightarrow \mathrm{O}_{2} \ldots .
\end{gathered}
$$

The differences reported in the radiolytic yields are due to the respective catalyst involved in the radiolytic splitting of water (Chemerisov et al. 2001; Gondal et al. 2004).

\section{References}

Arnikar Jeevan, H. (1987) Essential of Nuclear Chemistry, J. Wiley, ISBN 81-224-0712-9, New York, USA, pp.302-317

Asaftei, I.; Balba, N. \& Iofcea, Gh. (2002). Elements of catalysis. CERMI, ISBN 973-8188-08-3, Iasi, Romania, pp.172-183

Belloni, J. \& Mostafavi, M. (2001). Radiation chemistry, present status and future trends, in C.D. Jonah, B. M. Rao (eds), Elsevier, ISBN 0-444-82902-4, Amsterdam, Netherlands

Besenbuch,G. E.; Brown, L. C.; Funk, J. F. \& Sowalter, S. K. (2000). High Efficiency Generation of Hydrogen Fuels using nuclear power, in Nuclear production of hydrogen, First information. Exchange Meeting, Paris, France, 2-3 oct., pp. 205-218

Brewer, K. J. \& Elvington, M. (2006). Supramolecular Complexes as Photocatalysts for the Production of Hydrogen from Water, U. S. Patent, 7 pp.122

Cecal, Al.; Paraschivescu, A.; Popa, K.; Colisnic, D.; Timco, G. \& Singerean L. (2003). Radiolytic splitting of water molecules in the presence of some supramolecular compounds, Journal of Serbian Chemical Society, Vol.68, No. 7, pp. 593-598, ISSN 0352-5139

Cecal, Al.; Goanta, M.; Palamaru, M.; Stoicescu, T.; Popa, K.; Paraschivescu, A. \& Anita, V. (2001). Use of some oxides in radiolytical decomposition of water, Radiation Physics and Chemistry, Vol.62, No.4 pp. 333-336, ISSN 0969-806X

Cecal, Al.; Colisnic, D.; Popa, K; Paraschivescu, A.; Bilba, N. \& Cozma, D. (2004). Hydrogen yield from water radiolysis in the presence of zeolites. Central European Journal of Chemistry, Vol.2, No.2, pp. 247-253, ISSN 1895-1066 
Cecal, Al.; Hauta, O.; Macovei, A.; Popovici, E.; Rusu, I. \& Puica Melniciuc, N. (2008). Hydrogen Yield from watrer radiolysis in the presence of some pillared clays. Revue Roumaine de Chimie, Vol. 53, No. 9, pp. 875-880, ISSN 0035-3930

Chemerisov, S.C; Werst, D. W. \& Trifunac, A. D.; (2001). Formation, trapping and kinetics of $\mathrm{H}$ atoms in wet zeolites and mesoporous silica. Radiation Physics and Chemistry, Vol. 60, No.4-5, pp. 405-410, ISSN 0969-806X

Ferradini, C. \& Pucheault, J. (1983). Biologie de l'action des rayonnements ionisants, Messon, ISBN 2-225-78859-6, Paris, France, pp.6-22

Gondal M. A.; Hameed, A.; Yamani, Z. N. \& Suwaiyan, A. (2004). Production of hydrogen and oxygen by water splitting using induced photo-catalysis over $\mathrm{Fe}_{2} \mathrm{O}_{3}$. Applied Catalysis A:General, Vol. 268, No.1-2, pp. 159-167, ISSN 0926-860X

Hauta, O.; Macovei, A.; Apostolescu, G.; Ganju, D. \& Cecal, Al. (2009). Radiolytic output of hydrogen as environmentally friendly energy vector. Environmental Engineering and Management Journal, Vol. 8, No. 1, pp. 91-95, ISSN 1582-9596

Henglein, A; Schnabel, W \& Wendenburg, J. (1969). Einführung in die Strahlenchemie, Verlag Chemie, GmbH, Weinhelm, Germany, pp.20-25

Jung, J.; Jeong, S.; Chung, H. H.; Lee, M. J.; Jin, J. H. \& Park, K. B. (2003). Radiocatalytic $\mathrm{H}_{2}$ production with gamma-irradiation and $\mathrm{TiO}_{2}$ catalysts, Journal of Radioanalytical and Nuclear Chemistry, Vol.258, No.3, pp. 543-546, ISSN 0236-5731

Kiefer, J. (1989). Biologische Strahlenwirkung, Birkhauser Verlag, ISBN 3-7643-2266-7, Basel, Germany, pp.105-107

Majer, V. (1982). Grundlagen der Kernchemie, C. Hanser Verlag, ISBN: 3-446-13377-1 München, Germany, pp. 369-396

Maeda,Y.; Kawara, Y.; Kawamura,K.; Hayami, S.; Sugiuhara, S. \& Okai, T. (2005). Hydrogen Gas Evolution from Water Included in Silica Gel Cavity and on Metal Oxides with gamma-Ray Irradiation, Journal of Nuclear and Radiochemical Sciences, Vol.6, No.2, pp. 131-134, ISSN 1345-4749

Mastalir, A.; Rac, B.; Kraly, Z.; Tasi, G. \& Molnar, A. (2008). Preparation of monodispersed Pt nanoparticles in MCM-41 catalityc applications, Catalysis Communicatios, Vol.9, No.5, pp. 762-768, ISSN 1566-7367

Nakashima, M. \& Masaki,N. M. (1996). Radiolytic hydrogen gas formation from water adsorbed on type $\mathrm{Y}$ zeolites, Radiation Physics and Chemistry, Vol.47, No.2, pp. 241245, ISSN 0969-806X

Ohta, T. \& Veziroglu, T. N.(2006). Energy carriers and conversion systems with emphasis of hydrogen, in Energy Carriers and Conversion Systems, [Ed. Tokio Ohta], in Encyclopedia of Life Support Systems (EOLSS), Developed under the Auspices of the UNESCO, Eolss Publishers, Oxford ,UK, [http://www.eolss.net]

Popovici, E.; Humelnicu, D. \& Hristodor, C. (2006). Retention of $\mathrm{UO}_{2}{ }^{2+}$ ions from simulated residual waters on Romanian pillared clays. Revue Chimie (Bucharest), Vol. 57, No. 7, pp. 675-678, ISSN 0034-7752

Rahier, A.; Fonteyne, A.; Klein, M.; Ponnet, M.; Pirard, J. P. \& Germain, A. (2000). Hydrogen production associated to the treatment of nuclear wastes, in Nuclear production of hydrogen, First information. Exchange Meeting, Paris, France, 2-3 oct., pp. 197-204

Rotureau, P.; Renault, J. P.; Lebeau, B.; Patarin, J. \& Mialocq, J.-C. (2006). Radiolysis of Confined Water: Molecular Hydrogen Formation, ChemPhysChem, Vol.6, pp. 13161323, ISSN 439-4235 
Seino, S.; Yamamoto, T. A.; Fujimoto, R.; Hashimoto, K.; Katsura, M.; Okuda, S. \& Ohitsu, K. (2001). Enhancement of Hydrogen Evolution Yield from Water Dispersing Nanoparticles Irradiated with Gamma-Ray, Journal of Nuclear Science and Technology, Vol. 38, No.8, pp. 633-636, ISSN 0022-3131

Seino, S.; Yamamoto, T. A.; Fujimoto,R.; Hashimoto K.; Katsura, M.; Okuda, S.; Okitsu, K. \& Oshima, R. (2001). Hydrogen evolution from water dispersing nanoparticles irradiated with gamma-ray/size effect and dose rate effect, Scripta materialia, Vol.44, No.8-9, pp. 1709-1712, ISSN 1359-6462

Tashimo, M.; Kurasawa, A. \& Ikeda, K. (2004). Role of nuclear producted hydrogen for global environment and energy, in Nuclear Production of Hydrogen - Second Information Exchange Meeting Argonne, Illinois, USA, 2-3 oct. 2003, pp. 43-47

Van Olphen, H. (1963). An introduction to Clay Colloid Particle Technology, $1^{\text {th }}$ edition, Micromeritics Instrument Corp, Norcroos, Georgia, USA, pp.67-89

Verfondern, K. (Editor).(2007).Nuclear energy for hydrogen production, Schriften der Forshungszentrum Jülich: Reihe Energietechnik/Energy Technology, Vol. 58, ISBN 978-3-89336-468-8, Zentralbibliotek Verlag, D-52425 Jülich, Germany, pp.91-110

Veziroglu, T. N. (2000). Quarter century of hydrogen movement 1974-2000, International Journal of Hydrogen Energy, Vol.25, No.12, pp. 1143-1150, ISSN 0360-3199

Zholobenko, V. L.; Holmes, S. M.; Cundy, C.S. \& Dwyer, J. (1997). Synthesis of MCM-41 materials an in situ FTIR study, Microporous Materials, Vol. 11, No.1-2 , pp. 83-86, ISSN 1387-1811

Yamamoto, T. A.; Seino, S.; Katsura, M.; Okitsu, K.; Oshima, R. \& Nagata, Y. (1999). Hydrogen gas evolution from alumina nanoparticles dispersed in water irradiated with $\gamma$-ray, Nanostructured Materials, Vol.12, No.5-8, pp. 1045-1048, ISSN 0965-9773

Yildiz, M. \& Kazimi, S. (2006). Efficiency of Hydrogen Systems using Alternative Nuclear Energy Technologies, International Journal of Hydrogen Energy, Vol.31, No. 1, pp. 7792, ISSN 0360-3199

Yoshida, T.; Tanabe, T.; Sugie, N. \& Chen, A. (2007). Utilisation of gamma-ray irradiation production from water, Journal of Radioanalytical and Nuclear Chemistry, Vol.272, No.3, pp. 471-476, ISSN 0236-5731

http://satyen.baindur.org/. IAEA TecDoc-1085, Hydrogen as an Energy carriers and its production by nuclear power, May 1999, Safety issues in Nuclear Hydrogen production with the VHTR

http:// www.top-alternative-energy source.com/hydrogen-from-water.html. Hydrogen from water 


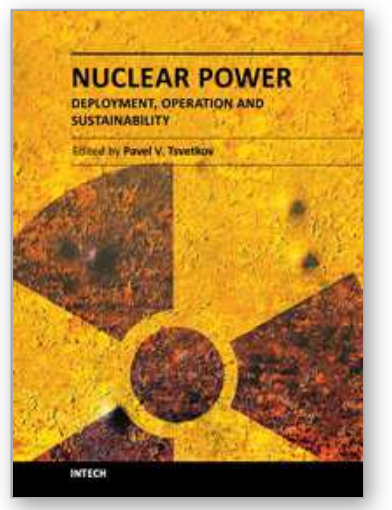

\author{
Nuclear Power - Deployment, Operation and Sustainability \\ Edited by Dr. Pavel Tsvetkov
}

ISBN 978-953-307-474-0

Hard cover, 510 pages

Publisher InTech

Published online 09, September, 2011

Published in print edition September, 2011

We are fortunate to live in incredibly exciting and incredibly challenging time. Energy demands due to economic growth and increasing population must be satisfied in a sustainable manner assuring inherent safety, efficiency and no or minimized environmental impact. These considerations are among the reasons that lead to serious interest in deploying nuclear power as a sustainable energy source. At the same time, catastrophic earthquake and tsunami events in Japan resulted in the nuclear accident that forced us to rethink our approach to nuclear safety, design requirements and facilitated growing interests in advanced nuclear energy systems. This book is one in a series of books on nuclear power published by InTech. It consists of six major sections housing twenty chapters on topics from the key subject areas pertinent to successful development, deployment and operation of nuclear power systems worldwide. The book targets everyone as its potential readership groups - students, researchers and practitioners - who are interested to learn about nuclear power.

\title{
How to reference
}

In order to correctly reference this scholarly work, feel free to copy and paste the following:

Alexandru Cecal and Doina Humelnicu (2011). Hydrogen Output from Catalyzed Radiolysis of Water, Nuclear Power - Deployment, Operation and Sustainability, Dr. Pavel Tsvetkov (Ed.), ISBN: 978-953-307-474-0, InTech, Available from: http://www.intechopen.com/books/nuclear-power-deployment-operation-andsustainability/hydrogen-output-from-catalyzed-radiolysis-of-water

\section{INTECH}

open science | open minds

\section{InTech Europe}

University Campus STeP Ri

Slavka Krautzeka 83/A

51000 Rijeka, Croatia

Phone: +385 (51) 770447

Fax: +385 (51) 686166

www.intechopen.com

\section{InTech China}

Unit 405, Office Block, Hotel Equatorial Shanghai

No.65, Yan An Road (West), Shanghai, 200040, China

中国上海市延安西路65号上海国际贵都大饭店办公楼405单元

Phone: +86-21-62489820

Fax: $+86-21-62489821$ 
(C) 2011 The Author(s). Licensee IntechOpen. This chapter is distributed under the terms of the Creative Commons Attribution-NonCommercialShareAlike-3.0 License, which permits use, distribution and reproduction for non-commercial purposes, provided the original is properly cited and derivative works building on this content are distributed under the same license. 